\title{
Epidemiology of infectious meningitis in the State of Amazonas, Brazil
}

\author{
Maria das Graças Gomes Saraiva ${ }^{[1],[2]}$, Eyde Cristianne Saraiva Santos ${ }^{[3]}$, \\ Valéria Saraceni ${ }^{[4]}$, Lívia Laura dos Santos Rocha ${ }^{[5]}$, Rossicléia Lins Monte ${ }^{[1]}$, \\ Bernardino Cláudio de Albuquerque ${ }^{[6]}$, Michele de Souza Bastos ${ }^{[1]}$, \\ Marcelo Cordeiro dos Santos ${ }^{[1],[7]}$, Wuelton Marcelo Monteiro ${ }^{[1]}$, \\ Maria Paula Gomes Mourão ${ }^{[1],[7]}$, Marcus Vinitius de Farias Guerra ${ }^{[1]}$ \\ and Marcus Vinícius Guimarães de Lacerda ${ }^{[1],[7]}$
}

[1]. Fundação de Medicina Tropical Doutor Heitor Vieira Dourado, Manaus, AM. [2]. Coordenação de Medicina, Universidade Nilton Lins, Manaus, AM. [3]. Departamento de Engenharia Agrícola e Solos, Faculdade de Ciências Agrárias, Universidade Federal do Amazonas, Manaus, AM. [4]. Secretaria Municipal de Saúde do Rio de Janeiro, Rio de Janeiro, RJ. [5]. Curso de Medicina, Universidade Federal do Amazonas, Manaus, AM. [6]. Fundação de Vigilância em Saúde, Manaus, AM. [7]. Coordenação de Medicina, Universidade do Estado do Amazonas, Manaus, AM.

\begin{abstract}
Introduction: In the State of Amazonas, particularly in the capital Manaus, meningitis has affected populations of different cultures and social strata over the years. Bacterial meningitis is caused by several different species and represents a major issue of public health importance. The present study reports the meningitis case numbers with different etiologies in Amazonas from January 1976 to December 2012. Methods: Since the 1970s, the (currently named) Tropical Medicine Foundation of Doutor Heitor Vieira Dourado [Fundação de Medicina Tropical Doutor Heitor Vieira Dourado (FMT-HVD)] has remained a reference center in Amazonas for the treatment of meningitis through the diagnosis and notification of cases and the confirmation of such cases using specific laboratory tests. Results: The foundation has achieved coverage of over $90 \%$ of the state medical records for many years. Between 1990 and 2012, meningitis cases caused by Haemophilus influenzae decreased with the introduction of the $H$. influenzae vaccine. Meningococcal disease previously had a higher frequency of serogroup B disease, but starting in 2008 , the detection of serogroup C increased gradually and has outpaced the detection of serogroup B. Recently, surveillance has improved the etiological definition of viral meningitis at FMT-HVD, with enteroviruses, Epstein-Barr virus (EBV) and varicella zoster virus (VZV) prevailing in this group of pathogens. With the advent of acquired immunodeficiency syndrome (AIDS), cryptococcal meningitis has become an important disease in Amazonas. Additionally, infectious meningitis is an important burden in the State of Amazonas. Conclusions: Changes in the epidemiological profile for the different etiology-defined cases are the result of continuous epidemiological surveillance and laboratory capacity improvements and control measures, such as Haemophilus influenzae vaccination.
\end{abstract}

Keywords: Meningitis. Epidemiology. Amazonas.

\section{INTRODUCTION}

Meningitis is a disease that affects the membranes surrounding the central nervous system (CNS) and is characterized by fever, headache, nausea, vomiting, meningeal irritation, and alterations in the cerebrospinal fluid (CSF). Meningitis is a serious disease, and the prognosis depends primarily on its early diagnosis and the provisioning of immediate and adequate

Corresponding author: Dra. Maria das Graças Gomes Saraiva. Depto. de Epidemiologia e Saúde Pública/Fundação de Medicina Tropical Doutor Heitor Vieira Dourado. Av. Pedro Teixeira 25, Dom Pedro, 69040-000 Manaus, AM, Brasil. Phone: 92 2127-3438; 92 9439-1290.

e-mail: gracasaraiva@fmt.am.gov.br

Received 23 May 2014

Accepetd 21 August 2014 treatment. Meningitis occurs worldwide, and its clinical and epidemiological characteristics are associated with infectious agents, socioeconomic characteristics of the population, and environmental factors. The disease is caused by various infectious and non-infectious agents, and the infectious agents, particularly bacteria and viruses, assume the greatest importance in public health, considering the scope of occurrence ${ }^{(1)}$.

Meningitis is a serious health problem because of its progression in severity, the potential risk of mortality, and severe sequelae ${ }^{(2)}$. The disease can affect individuals of all ages, although children under 1 year old are the most susceptible ${ }^{(3)}$. It is important to understand the epidemiological profile of the cases reported by public health services to improve diagnosis ${ }^{(4)}$. Meningitis often has signs and symptoms that suggest the clinical diagnosis, such as the classic triad of fever, headache and nuchal rigidity. Another example is the sudden onset of hemorrhagic rash accompanied by fever, which is a 
clinical criterion for the diagnosis of meningococcal disease ${ }^{(5)}$. However, updating the clinical data is important for updating the clinical patterns. Laboratory diagnosis of meningitis involves the study of the CSF, blood, and smears from petechial lesions. The main routine tests performed with the CSF include biochemical, cytological, conventional and molecular microbiological analyses $^{(1)}$.

The most important bacterial agents for this disease are Neisseria meningitidis, Streptococcus pneumoniae, Mycobacterium tuberculosis, and Haemophilus influenzae. Meningitis of viral origin may be caused by a variety of agents. However, the non-polio enteroviruses are the most common causative agents and include echovirus, Coxsackie virus A, and Coxsackie virus $\mathrm{B}^{4}$. In infants, tuberculous meningitis is caused by primary M. tuberculosis infection. In adults, tuberculous meningitis is mostly a complication of reactivated tuberculosis ${ }^{(1)}$. The fecal-oral route is of great importance in the spread of enteroviral infections. Since the spread of acquired immunodeficiency syndrome (AIDS), cryptococcal meningitis has been reported more frequently because of its strong association with $\operatorname{AIDS}^{(6)}$.

Neisseria meningitidis is the major bacterial agent that causes meningitis, and the species is classified into 12 different serogroups that are further subdivided into serotypes and subtypes $^{(7)}$. The transmission of meningococcal agents occurs through direct contact with droplets and secretions from the naso- or rhinopharynx of infected individuals (amounting to approximately $10 \%$ of the population) ${ }^{(3)(8)(9)}$, with incubation periods ranging from 2 to 10 days (averaging 3 to 4 days $^{(8)}$ ${ }^{(10)}$ ). Additionally, the disease is characterized by the sudden onset of clinical manifestations ${ }^{(8)}$. The transmission potential persists as long as $N$. meningitidis remains in the nasopharynx and usually disappears within $24 \mathrm{~h}$ of antibiotic therapy. The prevention of secondary meningococcal disease is based on the identification of intimate contact with the primary subjects with further chemoprophylaxis to interrupt transmission. The prevention of new meningococcal disease cases occurs through vaccination, when available ${ }^{(10)}$.

In general, the seasonality of meningitis is characterized by an increase in the number of bacterial meningitis cases in the winter and of viral meningitis in the summer ${ }^{(11)}$. In Manaus, the meningococcal disease incidence rate is higher in the rainy season, particularly in April and May ${ }^{(12)}$. In this city, the factors associated with the occurrence of meningitis are not well known, but it is suspected that the urban demographic expansion beginning in the 1970s has contributed to the spread of the disease.

\section{METHODS}

\section{Meningitis surveillance in the State of Amazonas}

At present, meningitis is part of the National List of Diseases of Compulsory Notification in accordance with Ordinance No. 5 from February 21, 2006 ${ }^{(13)}$. The Epidemiological Surveillance System for Meningitis [Sistema de Vigilância Epidemiológica das Meningites (SVE/Meningites)] involves several activities and actors, including the identification of suspected cases and the adoption of disease prevention and control measures in the community $^{(3)}$.

Surveillance System for Meningitis was launched in 1975 and aimed at controlling meningococcal diseases in view of the incidence of outbreaks in Brazil. At that time, the Coordination of Epidemiology [Coordenadoria de Epidemiologia (COOREP) had been established in State of Amazonas and was controlled by the State Secretariat of Health [Secretaria de Estado da Saúde (SESAU)], currently called the Secretariat of the State for Health, which is responsible for all of the epidemiological surveillance services in the state. In 1983, the first Epidemiological Surveillance Unit [Unidade de Vigilância Epidemiológica da Fundação de Medicina Tropical Doutor Heitor Vieira Dourado (UVE/FMT-HVD)] was created at the Institute of Tropical Medicine of Manaus (which later became the FMT-HVD), which was a reference center for the diagnosis and treatment of meningitis. The UVE/FMT-HVD served as the surveillance unit of the state surveillance system and played an important role in the reporting and investigation of meningitis, including outbreak investigation together with COOREP until May 1999. After June 1999, a decentralization of the epidemiological surveillance services gradually occurred in the state. However, the FMT-HVD continued to serve as the surveillance unit for the performance of clinical and laboratory diagnostics and epidemiological surveillance in Amazonas. In 2004, the Foundation for Health Surveillance of Amazonas was created, which is a state agency with the goal of aiding in the coordination and performance of epidemiological surveillance, in accordance with the current legislation.

\section{Data sources}

The present article describes a time series of recorded meningitis cases that were caused by $N$. meningitidis, H. influenzae type b (Hib), S. pneumoniae, and M. tuberculosis as well as cases of aseptic meningitis and cryptococcal meningitis in Amazonas. Data from the different information system levels were used to construct the time series.

Data regarding $N$. meningitidis disease were collected from the records of COOREP/SESAU and UVE/FMT-HVD for 1976 to 2012. H. influenzae type b, S. pneumoniae, and M. tuberculosis as well as aseptic meningitis data were collected from the UVE/FMT-HVD for 1990 to 2012. Cryptococcal meningitis data were collected from the UVE/FMT-HVD for 1986 to 2012. Specific viral etiology data were recorded from a more recently established laboratory surveillance system at the FMT-HVD in 2010.

\section{RESULTS}

Since 1976, the epidemiological surveillance services in State of Amazonas have recorded meningococcal disease cases every year, with a total of 2,007 cases reported through 2012, representing an average of 54.2 cases/year (Table 1). The incidence rate ranged from 0.5 cases per 100,000 inhabitants 
TABLE 1 - The meningococcal disease incidence and mortality rates in State of Amazonas, 1976 to 2012.

\begin{tabular}{|c|c|c|c|c|c|c|}
\hline Year & $\begin{array}{l}\text { Estimated } \\
\text { population }\end{array}$ & $\begin{array}{c}\text { Cases } \\
\mathrm{n}\end{array}$ & $\begin{array}{c}\text { Deaths } \\
\mathrm{n}\end{array}$ & $\begin{array}{c}\text { Lethality } \\
\%\end{array}$ & $\begin{array}{c}\text { Incidence per } 100,000 \\
\text { inhabitants }\end{array}$ & $\begin{array}{c}\text { Mortality per } 100,000 \\
\text { inhabitants }\end{array}$ \\
\hline 1976 & $1,217,729$ & 22 & 7 & 31.8 & 1.8 & 0.6 \\
\hline 1978 & $1,320,390$ & 16 & 6 & 37.5 & 1.2 & 0.5 \\
\hline 1981 & $1,518,000$ & 9 & 2 & 22.2 & 0.6 & 0.1 \\
\hline 1982 & $1,569,000$ & 13 & 1 & 7.7 & 0.8 & 0.1 \\
\hline 1983 & $1,621,000$ & 8 & 2 & 25.0 & 0.5 & 0.1 \\
\hline 1987 & $1,805,044$ & 17 & 0 & 0.0 & 0.9 & 0.0 \\
\hline 1988 & $1,961,282$ & 12 & 5 & 41.7 & 0.6 & 0.3 \\
\hline 1989 & $1,979,597$ & 51 & 15 & 29.4 & 2.6 & 0.8 \\
\hline 1990 & $2,037,078$ & 16 & 8 & 50.0 & 0.8 & 0.4 \\
\hline 1991 & $2,102,775$ & 27 & 10 & 37.0 & 1.3 & 0.5 \\
\hline 1992 & $2,155,090$ & 29 & 14 & 48.3 & 1.3 & 0.6 \\
\hline 1993 & $2,217,600$ & 43 & 22 & 51.2 & 1.9 & 1.0 \\
\hline 1999 & $2,580,860$ & 103 & 16 & 15.5 & 4.0 & 0.6 \\
\hline 2000 & $2,813,085$ & 131 & 15 & 11.5 & 4.7 & 0.5 \\
\hline 2001 & $2,900,240$ & 132 & 22 & 16.7 & 4.6 & 0.8 \\
\hline 2002 & $2,961,801$ & 142 & 21 & 14.8 & 4.8 & 0.7 \\
\hline 2003 & $3,031,068$ & 117 & 22 & 18.8 & 3.9 & 0.7 \\
\hline 2004 & $3,147,848$ & 100 & 11 & 11.0 & 3.2 & 0.3 \\
\hline 2005 & $3,232,330$ & 65 & 11 & 16.9 & 2.0 & 0.3 \\
\hline 2006 & $3,311,026$ & 57 & 16 & 28.1 & 1.7 & 0.5 \\
\hline 2007 & $3,221,939$ & 60 & 13 & 21.7 & 1.9 & 0.4 \\
\hline 2008 & $3,341,096$ & 55 & 15 & 27.3 & 1.6 & 0.4 \\
\hline 2009 & $3,393,369$ & 59 & 9 & 15.3 & 1.7 & 0.3 \\
\hline 2010 & $3,480,937$ & 30 & 6 & 20.0 & 0.9 & 0.2 \\
\hline 2011 & $3,538,359$ & 26 & 7 & 26.9 & 0.7 & 0.2 \\
\hline 2012 & $3,590,985$ & 29 & 8 & 27.6 & 0.8 & 0.2 \\
\hline
\end{tabular}


in 1983 and 1984 to 5.5 cases per 100,000 inhabitants in 1996. Over the past 15 years, there has been a gradual decrease in the detection rates of meningococcal diseases in the state, ranging from 5.2 cases per 100,000 inhabitants in 1998 to 0.8 cases per 100,000 inhabitants in 2012. During this period, 439 deaths occurred, representing an average fatality rate of $21.9 \%$. Of note, the mortality was higher prior to the early 1990s, when it reached more than 50\%, as reported in 1979 and 1993. Over the past 15 years, the average mortality rate was approximately $20 \%$.

Figure 1 shows the proportion of viral and bacterial meningitis cases with defined etiologies in Amazonas from 1990 to 2012. Since 2009, there has been a slight decrease in the number of cases caused by $H$. influenzae and a slight increase in the number of cases caused by $S$. pneumoniae. The incidences of meningitis cases due to $N$. meningitidis and H. influenzae as well as cases of viral meningitis have decreased over the past 15 years. This decrease was most pronounced for H. influenzae (Figure 1).

Over this 23-year period (1990-2012), 3,850 meningitis and meningococcemia cases were reported. Of these cases, 3,663 (95.1\%) cases had a defined etiology, and $187(4.9 \%)$ were pathogen-unspecified. Of the total number of cases with a defined etiology, 3,009 (82.1\%) were classified as bacterial meningitis cases (excluding tuberculosis), $481(13.1 \%)$ as aseptic, $126(3.5 \%)$ as tuberculous, $28(0.8 \%)$ as cryptococcal, and
$19(0.5 \%)$ as other fungal, protozoan, or helminthic etiologies. With respect to the bacterial meningitis cases (excluding tuberculosis), 873 (23.8\%) were due to $N$. meningitidis, $192(5.2 \%)$ were due to $H$. influenzae type b, $175(4.8 \%)$ were due to $S$. pneumoniae, and 1,769 (48.3\%) had no bacteria specified.

Of the 1,730 meningococcal disease cases reported from 1990 onwards, 897 (51.8\%) had no capsular group information recorded, 723 (41.8\%) were due to group B, and $110(6.4 \%)$ were due to group C. In 2000, the first case belonging to serogroup C was diagnosed, and from 2008, the number of cases from this serogroup surpassed serogroup B. Beginning in 2010, a gradual decrease in the number of cases belonging to group $\mathrm{B}$ was observed (Figure 2). From a total of 259 meningococcal disease cases reported from 2007 to 2012 in patients with known ages, $17(6.6 \%)$ cases were reported in children under 1 year old, $41(15.8 \%)$ in children aged 1 to 4 years, $76(29.3 \%)$ in children aged 5 to 14 years, and $125(48.3 \%)$ in individuals over 14 years old. The proportional age distribution was heterogeneous. However, for children under 1 year old, we noticed a reduction in the number of meningococcal disease cases in the previous 2 years (Figure 3 ).

The viral meningitis laboratory surveillance system at FMT-HVD, by using different combinations of molecular techniques (PCR, RT-PCR and Semi-Nested PCR), identified $29.7 \%$ of the agents responsible for aseptic meningitis

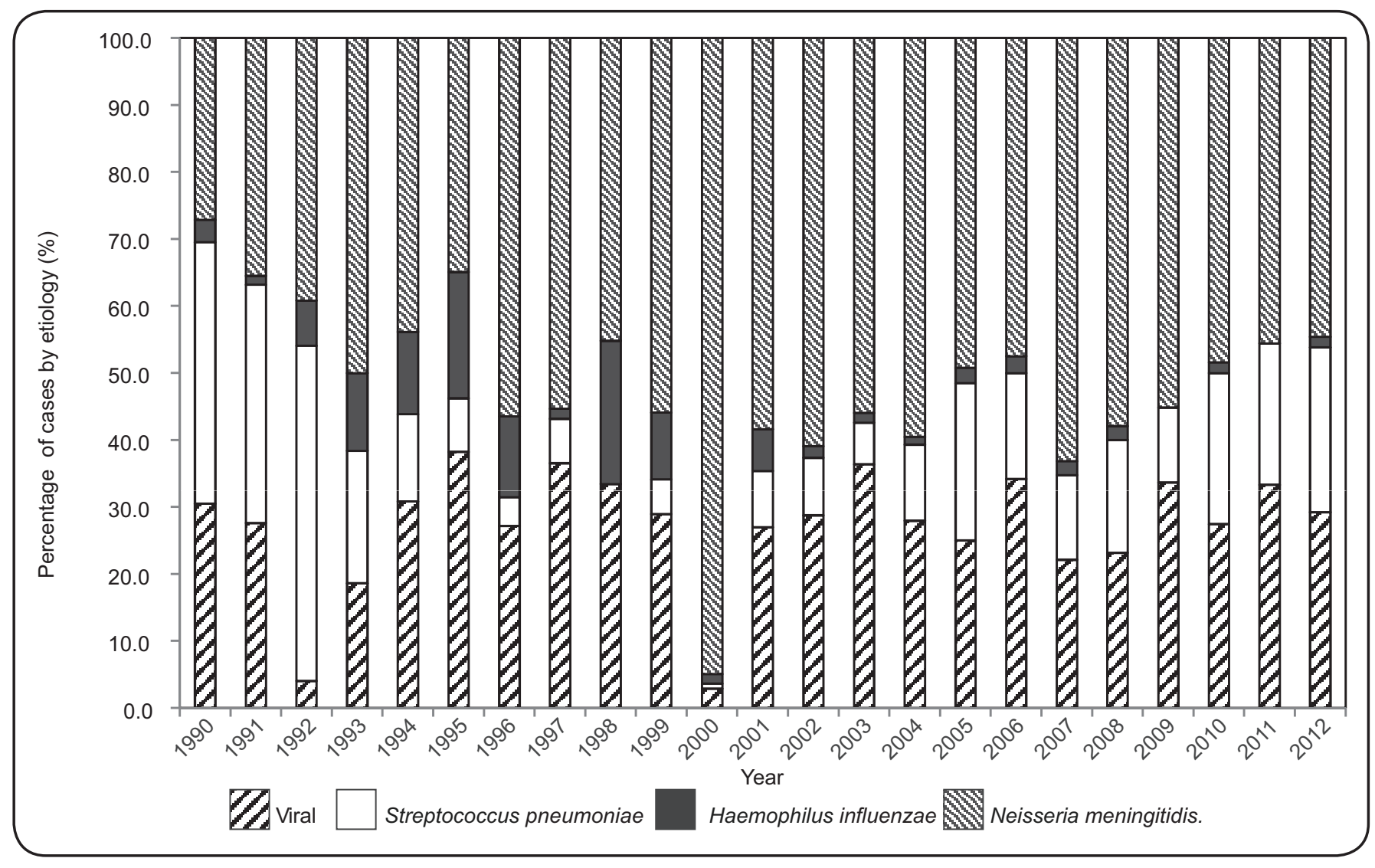

FIGURE 1 - Percent distribution of the major meningitis etiologies in State of Amazonas from 1990 to 2012. 


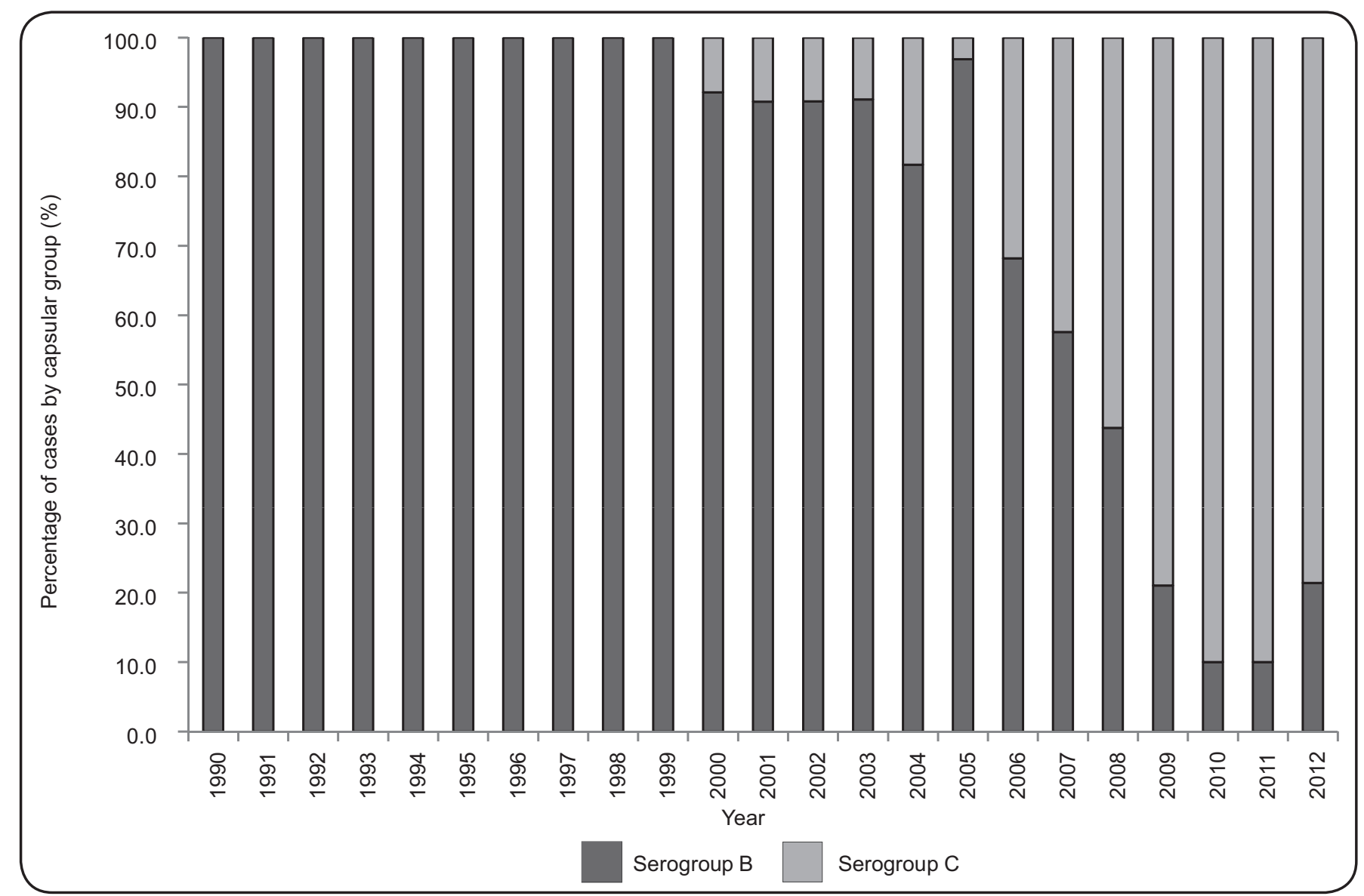

FIGURE 2 - Percent distribution of meningococcal disease cases with capsular group information recorded in State of Amazonas from 1990 to 2012.

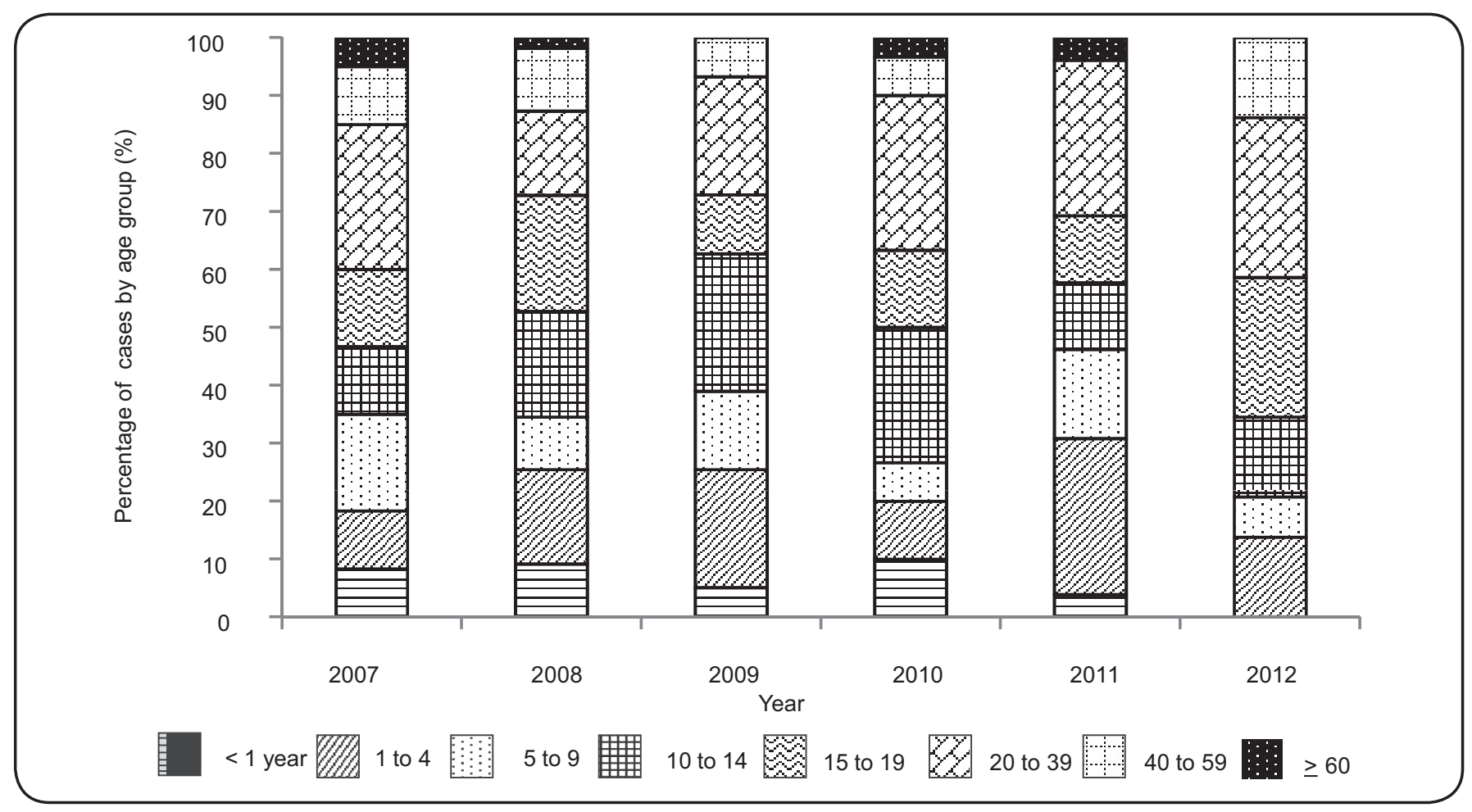

FIGURE 3 - Percent distribution of meningococcal disease cases identified in State of Amazonas from 2007 to 2012 according to age group. 


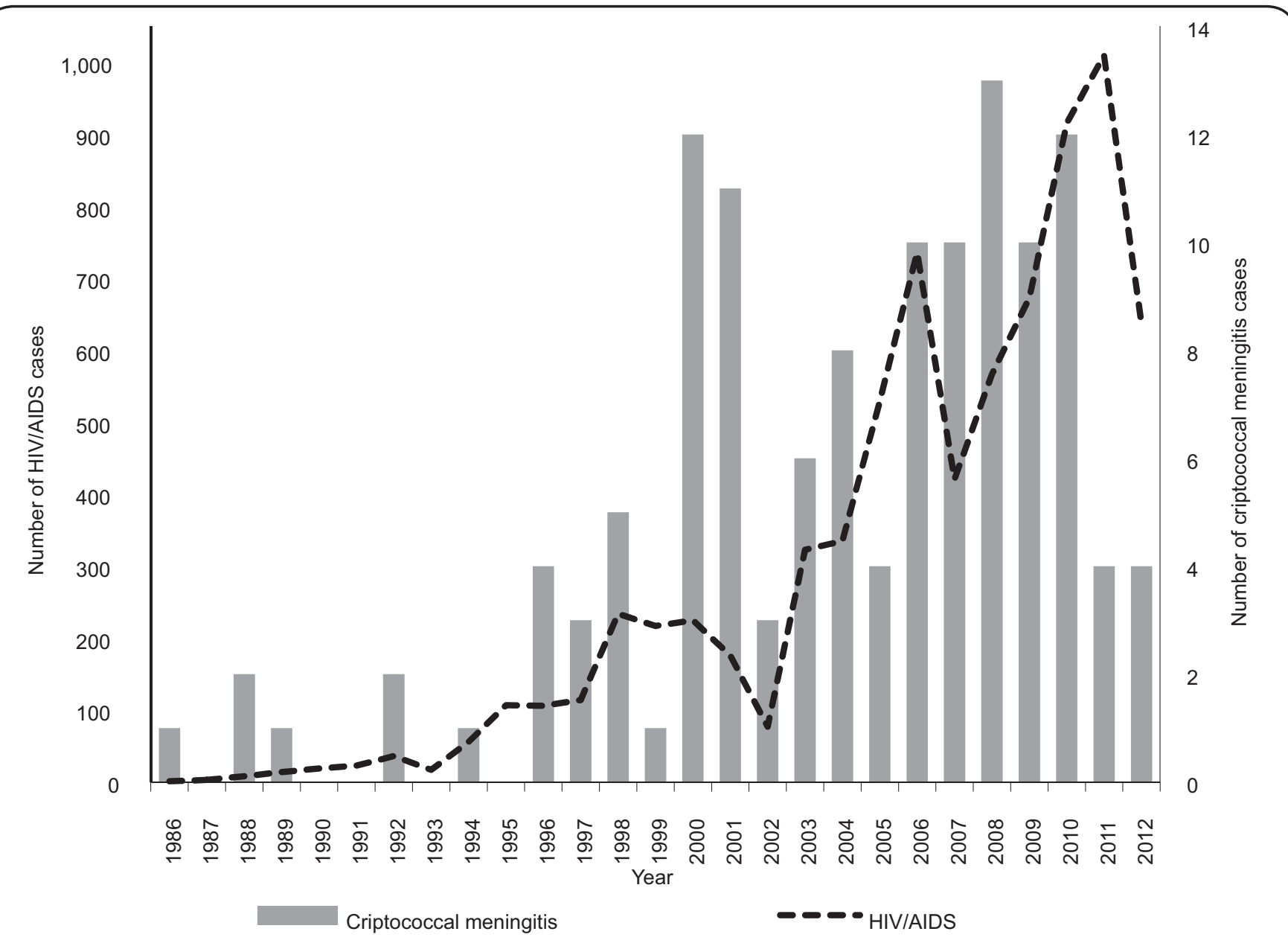

HIV: human immunodeficiency virus; AIDS: acquired immunodeficiency syndrome.

FIGURE 4 - Distribution of patients living with HIV/AIDS and cryptococcal meningitis reported at the time of AIDS notification among residents in State of Amazonas, 1986-2012.

from 2010 onward. Enteroviruses were the most prevalent agents and were detected in $16(32.6 \%)$ positive samples, followed by Epstein-Barr virus (EBV) in $11(22.4 \%)$ samples, varicella zoster virus (VZV) in $10(20.4 \%)$ samples, cytomegalovirus (CMV) in $9(18.4 \%)$ samples, herpes simplex virus-1 (HSV-1) and HSV-2 in 2 (4.1\%) samples each, and arboviruses in $7(14.3 \%)$ samples, including 4 dengue virus and 3 oropouche virus $(\mathrm{OROV})^{(14)(15)}$. Simultaneous infection with 2 different viruses causing meningoencephalitis was detected in $8(16.4 \%)$ of the evaluated patients, and the associations with CMV/VZV and $\mathrm{EV} / \mathrm{EBV}$ were more frequent ${ }^{(15)}$.

The disease case database from the UVE/FMT-HVD, which is also a reference for the surveillance of human immunodeficiency virus (HIV)/AIDS in State of Amazonas, allowed for the evaluation of AIDS-related cryptococcal meningitis cases from 1986 to 2012 and indicated a correlation between these diseases (Figure 4).

\section{DISCUSSION}

In the present study, it was possible to collect data on the morbidity and mortality of meningococcal diseases from 1976 to 2012. These cases are an important public health issue in the state, particularly considering the lethality of this disease. In this period, a high average mortality rate was observed, and the mortality reached more than $50 \%$ in some years. In most countries, $N$. meningitidis is a leading cause of meningitis and sepsis as well as a significant cause of death and disability in children below five years of age ${ }^{(16)}$.

The last outbreak of meningococcal diseases due to serogroup C identified in Amazonas was in Eirunepé in 2009, with 5 recorded cases and no deaths ${ }^{(17)}$. In this state, the first peak in the curve of meningococcal cases recorded since 1976 occurred in 1989, followed by another increase in 1996, and this increase was maintained until 2002, with 142 reported cases. 
Most meningococcal disease notifications, including meningitis, come from Manaus ${ }^{(12)(18)}$. However, the occurrence of cases in the remote areas of the state has been reported, with a differential diagnosis of hemorrhagic fever in the Amazon forest, where it can be mistaken for diseases caused by viruses or other agents ${ }^{(19)}$. In Brazil, in the 1970s and 1980s, epidemics were recorded in various cities that were caused most commonly by serogroups $\mathrm{A}$ and $\mathrm{C}$ followed by serogroup $\mathrm{B}^{(20)}$. However, starting in the 1990s, there was a proportional decrease in serogroup B and a progressive increase in serogroup $\mathrm{C}$, as observed in the City of Rio de Janeiro ${ }^{(5)}$. From that period onwards, meningococcal diseases remained endemic in the country, and isolated outbreaks of serogroup $\mathrm{C}^{(1)}$ have been identified, as expected considering the cyclic behavior of meningococcal diseases ${ }^{(21)}$.

In Brazil in the 1970s, in the face of the great epidemic of meningococcal diseases, a national vaccination campaign was conducted using the meningococcal vaccine $\mathrm{A} / \mathrm{C}$, resulting in the interruption of the circulation of serogroup $\mathrm{A}$ and the predominance of serogroups B and C. In the second half of 2010, the conjugate vaccine against serogroup $\mathrm{C}$ for children under 1 year of age became available ${ }^{(11)}$. In Amazonas, the incidence of meningitis cases caused by $N$. meningitidis has decreased over the past 15 years, particularly in children in the last 2 years of the study period. In this study, a shift in the serogroup predominance was observed in the region such that serogroup B predominated over serogroup C until 2007. Since the introduction of vaccination therapy against serogroup $\mathrm{C}$ in 2010 for children under 1 year old, the age pattern has started to shift towards older age groups.

We observed a slight decrease in the number of meningitis cases caused by $H$. influenzae and an increase in the number of S. pneumoniae cases between 1990 and 2012. The incidence of meningitis cases caused by $N$. meningitidis, $H$. influenzae, and viral pathogens decreased in the last 15 years. This decrease was more pronounced for $H$. influenzae. In turn, the incidence of cases caused by $S$. pneumoniae remained stable over the study period. With regards to meningitis caused by $H$. influenzae type $\mathrm{b}$, the number of cases decreased in State of Amazonas as well as on a national scale, owing to the introduction of the anti-Hib vaccine in $1999-2000^{(22)(23)(24)}$.

Infectious meningitis is responsible for several infectious disease cases in State of Amazonas. The gradual improvement in the identification of the causative agents has been essential; however, early diagnosis remains a challenge in the region. At present, within the national vaccination program, 3 vaccine types are available: a tetravalent (against $H$. influenzae), a 10-valent pneumococcal conjugate, and a meningococcal conjugate $\mathrm{C}$. All of these vaccines are freely available in 3 doses and can be administered in children older than 2 months of age.

Viral or aseptic meningitis is of great importance in the epidemiology of meningitis, with approximately $40 \%$ of notifications being registered in the country in $2011^{(17)}$, with Amazonas representing one-third of these cases in the same year. Notwithstanding this surveillance, we should emphasize the lack of data regarding the etiology of this meningitis type in State of Amazonas. The identification of the causative agents of viral meningitis in Brazil has only been possible in some situations, such as during outbreaks when there is a concerted surveillance effort for the etiologic agent. Therefore, the viral meningitis epidemiological surveillance system has limited information regarding the major causative agents. In the FMTHVD, the implementation of the laboratory surveillance system for the monitoring and identification of different viral agents has led to an improvement in the diagnostic system, and rapid, sensitive, and accurate identifications have been achieved in routine assistance care.

Enteroviruses were more prevalent in the studied population, confirming that these viruses are the most common cause of infection in the CNS. The rapid identification of the Herpesviridae virus family contributes to important clinical decisions, especially regarding the use of antiviral therapy for this group of viruses, which can lead to a decrease in mortality and disease sequelae ${ }^{(15)}$. Of note, arboviruses were also very frequent, and this etiology is probably underestimated, especially in immunocompromised patients and patients with previous blood-brain barrier impairments ${ }^{(14)}$.

Despite its opportunistic and rare nature, cryptococcal meningitis is still diagnosed among patients living with HIV, most likely because of a late diagnosis or treatment failure with antiretroviral compounds ${ }^{(25)}$. Cryptococcal cases have been reported in Amazonas since 1986 and reached a peak in 2008. In the present study, we verified that the cryptococcal meningitis cases were associated with HIV/AIDS during that time. In 2011 and 2012, there was a decrease in the number of cryptococcal cases, suggesting an improvement in the health assistance of patients living with HIV/AIDS, which prevented the occurrence of opportunistic cases.

In Amazonas, the FMT-HVD has been a reference service for the diagnosis and treatment of tropical and infectious diseases and for the training of human personnel to subsidize the adequate and immediate treatment of meningitis. Over the years, this institution has improved its clinical and laboratory meningitis diagnostics and maintained a partnership with the Adolfo Lutz Institute in São Paulo for laboratory quality control. For laboratory bacterial meningitis diagnoses, RT-PCR using CSF is highly sensitive and specific and has substantially added to measures of meningitis disease burden when incorporated into routine public health surveillance in some sites in Brazil ${ }^{(2)}$. Molecular techniques have not yet been incorporated into the routine diagnostic services for bacterial meningitis in Amazonas, which may explain the large number of cases of unknown etiology. Given the public health impact and potential to prevent meningitis through vaccination, further investigation is warranted to elucidate the clinical epidemiology of meningitis in this region.

The decentralization of the epidemiological surveillance services should not be considered an important factor in lowering the number of reported cases of meningitis. In contrast, the incorporation of vaccine therapy into the national immunization program should lower the number of cases. However, the continued training of health professionals in early diagnosis, adequate and immediate treatment, and maintenance of an effective epidemiological surveillance is fundamental to maintaining the low incidence of meningitis and prevent deaths. 


\section{ACKNOWLEDGMENTS}

The authors are thankful to the professionals involved in the implementation of the epidemiological surveillance system in State of Amazonas, particularly those working at the Surveillance Foundation of the State of Amazonas and at the FMT-HVD.

\section{CONFLICT OF INTEREST}

The authors declare that there is no conflict of interest.

\section{FINANCIAL SUPPORT}

We also thank the Foundation for Research Support of the State of Amazonas and the National Council for Scientific and Technological Development for their support.

\section{REFERENCES}

1. Miranda ECBM, Silva BM, Oliveira BPR. Meningites. In: Leão RNQ, editor. Doenças Infecciosas e Parasitárias. Enfoque Amazônico. Pará: Editora CEJUP; 1997. p. 171-189.

2. Almeida R, Oliveira A, Cleto E, Cardoso L, Vieira L, Morais L, et al. Meningites - Estudo descritivo de uma população pediátrica do Norte e centro de Portugal. Rev Hosp Criança Maria Pia 2003; XII:4. p. 299-308.

3. Ministério da Saúde. Secretaria de Vigilância em Saúde. Meningites. Guia de Vigilância Epidemiológica. $7^{\text {th }}$ ed. Caderno 12. Brasília: Ministério da Saúde 2010; p. 21-47.

4. Carvalho FF, Kreuz AC, Carvalho DG, Pádua MJ. Perfil dos casos de meningite internados no Hospital Materno Infantil de Marília, São Paulo, entre 2000 e 2005. Rev Paul Pediatr 2007; 25:10-15.

5. Barroso DE, Carvalho DM, Casagrande ST, Rebelo MC, Soares $\mathrm{V}$, Zahner V, et al. Microbiological epidemiological history of meningococcal disease in Rio de Janeiro, Brazil. Braz J Infect Dis 2010; 14:242-251.

6. Ministério da Saúde. Secretaria de Vigilância em Saúde. Programa Nacional de DST e AIDS. Critérios de definição de casos de Aids em adultos e crianças. Série Manuais. Brasília: Ministério da Saúde. 2003; 60:1-56.

7. Barroso DE, Pedro LGF, Machado SC. Doença meningocócica. In: Coura JR, editor. Dinâmica das Doenças Infecciosas e Parasitárias. Rio de Janeiro: Editora Guanabara; 2005. p. 1449-1452.

8. Meira DA. Doença meningocócica. In: Veronesi R, Focaccia R, editors. Doenças infecciosas e parasitárias. São Paulo: Editora Atheneu; 2004. p. 645-654.

9. Diamend D, Conceição OJG, Focaccia R. Meningococcemia. In: Tavares W, Marinho LAC, editors. Rotinas de diagnóstico e tratamento das doenças infecciosas e parasitárias. São Paulo: Editora Atheneu; 2007. p. 706-710.

10. Barroso DE, Carvalho DM, Nogueira AS, Solori CA. Doença meningocócica: epidemiologia e controle dos casos secundários. Rev Saude Publica 1998; 32:89-97.
11. Ministério da Saúde. Secretaria de Vigilância em Saúde. Meningites. Aspectos epidemiológicos. Brasília: Ministério da Saúde; 2013. (Cited 2013 June 2). Available at: http://portal.saude.gov.br/portal/ saude/profissional/visualizar_texto.cfm?idtxt $=31959$

12. Santos ECS. Perfil epidemiológico e distribuição espacial da doença meningocócica na cidade de Manaus, Amazonas - Brasil. (Monografia de Especialização em Saúde e Ambiente). (Manaus): Instituto Leônidas e Maria Deane, Fundação Oswaldo Cruz; 2010. p. 1- 31 .

13. Ministério da Saúde. Portaria $N^{\circ}$ 5, de 21 de fevereiro de 2006. Dispõe sobre as doenças de notificação compulsória no Brasil. Publicada no DOU n ${ }^{\circ} .38$ de 22 de fevereiro de 2006. Seção I. p. 34. Brasília: Ministério da Saúde; 2006.

14. Bastos MS, Figueiredo LT, Naveca FG, Monte RL, Lessa N, Pinto de Figueiredo RM, et al. Identification of Oropouche Orthobunyavirus in the cerebrospinal fluid of three patients in the Amazonas, Brazil. Am J Trop Med Hyg 2012; 86: 732-735.

15. Bastos MS, Lessa N, Naveca FG, Monte RL, Braga WS, Figueiredo LTM, et al. Detection of Herpesvirus, Enterovirus and Arbovirus infection in patients with suspected central nervous system viral infection in the Western Brazilian Amazon. J Med Virol 2014; 86:1522-1527.

16. World Health Organization. Meningococcal vaccines: WHO position paper. Wkly Epidemiol Rec 2011; 86: 521-539.

17. Ministério da Saúde. Secretaria de Vigilância em Saúde. Meningites. Aspectos epidemiológicos. Brasília: Ministério da Saúde; 2013. (Cited 2013 September 4). Available at: http://www.suvisa.ba.gov. $\mathrm{br} / \mathrm{sites} / \mathrm{default} / \mathrm{files} /$ vigilancia epidemiologica/imunopreveniveis/ arquivo/2012/08/09/Situ\%20Epid\%20Meningites_Camila\%20 Portela_03\%2007\%202012.pdf

18. Saraiva MGG, Monte RL, Soares GM, Albuquerque BC, Amorim RDS, Guerra MVF. Perfil epidemiológico da doença meningocócica em relação às meningites por outras causas com registro na FMT/ IMT-AM em 2002. Rev Soc Bras Med Trop 2003; 36:136.

19. Barroso DE, Silva LA. Neisseria meningitidis: a neglected cause of infectious haemorrhagic fever in the amazon rainforest. Braz J Infect Dis 2007; 11:598-602.

20. Moraes JC, Barata RB. Meningococcal disease in São Paulo, Brazil, in the 20th century: epidemiological characteristics. Cad Saude Publica 2005; 21:1458-1471.

21. Rosenstein NE, Perkins BA, Stephens DS, Lefkowitz L, Cartter ML, Danila R, et al. The changing epidemiology of meningococcal disease in the United States, 1992-1996. J Infect Dis 1999; 180:18941901.

22. Stella-Silva N, Oliveira SA, Marzochi KB. Meningococcal disease: comparison between clinical forms. Rev Soc Bras Med Trop 2007; 40:304-310.

23. Ministério da Saúde. Sistema de Planejamento SUS. Uma construção coletiva. Plano Nacional de Saúde, 2008/2009-2011. Caderno de Planejamento. Brasília: Ministério da Saúde 2010; 9:18.

24. Miranzi SS, de Moraes SA, de Freitas IC. Impact of the Haemophilus influenzae type b vaccination program on HIB meningitis in Brazil. Cad Saude Publica 2007; 23:1689-1695.

25. Grangeiro A, Escuder MM, Pereira JC. Late entry into HIV care: lessons from Brazil, 2003 to 2006. BMC Infect Dis 2012; 12:99.

26. Sacchi CT, Fukasawa LO, Gonçalves MG, Salgado MM, Shutt KA, Carvalhanas TR, et al. Incorporation of Real-Time PCR into Routine Public Health Surveillance of Culture Negative Bacterial Meningitis in São Paulo, Brazil. PLoS ONE 2011; 266:e20675. 